\title{
$\alpha$-Glycerophosphate Dehydrogenase Activity in Flight Muscles of Triatomine Bugs Panstrongylus megistus and Triatoma sordida
}

\author{
Rodrigo Pedro Pinto Soares/ ${ }^{+}$, Marcelo Matos Santoro ${ }^{*}$
}

Centro de Pesquisas René Rachou-Fiocruz, Av. Augusto de Lima 1715, 30190-002 Belo Horizonte, MG, Brasil *Departamento de Bioquímica e Imunologia, Universidade Federal de Minas Gerais, 31270-901 Belo Horizonte, MG, Brasil

The $\alpha$-glycerophosphate dehydrogenase $(\alpha-G P D H)$ activity in flight muscles of Panstrongylus megistus and Triatoma sordida, vectors of Chagas disease in Brazil, was studied. Both species showed higher enzymatic activities in fliers than in non-fliers insects. T. sordida exhibited a higher proportion of flier insects than P. megistus. A possible role of $\alpha-G P D H$ on triatomines flight is discussed.

Key words: triatomines - flight activity - $\alpha$-glycerophosphate dehydrogenase

Triatomine bugs (Hemiptera: Reduviidae: Triatominae) are the vectors of Trypanosoma cruzi, the causative agent of Chagas disease in Latin America. In recent years many efforts have been made to control the vectors of $T$. cruzi in Brazil and in other countries. Although these attempts have been successful there is concern that new triatomine vector species might take the place of the ones being exterminated. The ability of triatomines to disperse between different habitats may have important consequences on the reinfestation of dwellings and control programmes directed against them.

There are many records of sylvatic species of Triatominae flying into houses at night, apparently attracted by the light; also, several species seem to be progressively adapting from sylvatic to domestic habitats (Noireau et al. 1995, Valente et al. 1995). Panstrongylus megistus occupies a range of sylvatic habitats in Brazil but frequently colonizes houses and peridomestic ecotopes (Forattini et al. 1977), while Triatoma sordida has an even wider range of sylvatic and peridomestic habitats

\footnotetext{
This work was supported by $\mathrm{CNPq}$ and Fiocruz, Brazil, and benefited from international collaboration through the ECLAT network.

${ }^{+}$Corresponding author. Fax: + 55-31-295.3115. E-mail: rodrigo@cpqrr.fiocruz.br

Received 18 October 1999

Accepted 23 February 2000
}

and is thought to be in the process of domiciliation (Diotaiuti et al. 1993). Both laboratory and field experiments, show that flight initiation is influenced primarily by low nutritional status and above average temperatures (Lehane et al. 1992). Nevertheless, there are invariably some bugs that do not initiate flight even under apparently optimum conditions.

Cytoplasmic $\alpha$-glycerophosphate dehydrogenase $(\alpha-\mathrm{GPDH})$ is involved in a variety of functions in both carbohydrate and lipid metabolism. In the Diptera order, $\alpha$-GPDH is particularly important in the glycerophosphate cycle of flight muscle, through which glycolysis is coupled to oxidative phosphorylation. This cycle regenerates $\mathrm{NAD}^{+}$in the cytoplasm and provides reducing equivalents as $\mathrm{FADH}_{2}$ for ATP synthesis within the mitochondria (Sacktor 1970). In wasps and bees, $\alpha$-GPDH synthesis correlates with age and flight capacity (Machado \& Contel 1991), while in Drosophila thoracic $\alpha$-GPDH activity increases gradually as the adult insect becomes able to fly (Sullivan et al. 1983). Demonstration of the aGPDH role in Drosophila flight was emphasised by O'Brien and MacIntyre (1972) who showed that flies bearing a mutation at the $\alpha$-GPDH locus were unable to fly. In the Triatominae, $\alpha-$ GPDH is one of the few glycolytic enzymes showing a degree of polymorphism (Dujardin et al. 1998) and our aim in this work was to see if there was any correlation between $\alpha$-GPDH activity and the flight capacity of Triatominae. For this study we used adult $P$. megistus and $T$. sordida from different regions of Brazil. The P. megistus colony originated from 
the State of Minas Gerais, but had been reared for several years under laboratory conditions $(27 \pm$ $2{ }^{\circ} \mathrm{C}, 60 \pm 5 \% \mathrm{RH}$ ), whereas T. sordida was captured from peridomestic habitats in Serra do Ramalho, State of Bahia, Brazil. Fifty males and 50 females from each population were used in each experiment. The bugs were fed for $30 \mathrm{~min}$ on anaesthetized mice and the following day were placed in an actograph (Lehane \& Schofield 1981) under controlled laboratory conditions $\left(28 \pm 1{ }^{\circ} \mathrm{C}\right.$ and $42 \pm 2 \% \mathrm{RH})$. The insects were observed daily for a period of 30 days, in order to separate fliers from non-fliers. Those that flew were removed and stored in liquid nitrogen prior to extraction of thoracic muscles. Insects that did not fly after 30 days were considered non-fliers and were also stored in liquid nitrogen. Frozen bugs had their thoracic flight muscles removed, homogenized with $100 \mu \mathrm{l}$ of enzyme stabilizer ( $2 \mathrm{mM}$ dithiotreitol, $2 \mathrm{mM}$ aminocaproic acid and 2mM EDTA, pH 7.3) and centrifuged at $15,000 \mathrm{~g}$ at $4^{\circ} \mathrm{C}$. Activity of $\alpha$-GPDH was assayed spectrophotometrically at $25^{\circ} \mathrm{C}$, following the production of NADH at $340 \mathrm{~nm}$ upon substrate addition (Chambers et al. 1985). Protein concentrations were determined as described by Bradford (1976), using bovine serum albumin as the standard. The specific activity is given in Units/ $\mathrm{mg}$ of protein in muscle extracts.

In this experiment, the flight capacity of $T$. sordida (52\% fliers) was higher than that of $P$. megistus (15\% fliers), and $\alpha$-GPDH activity was significantly higher in fliers than in non-fliers in both species (Students t-test, $\mathrm{p}<0.05$ ) (Table).

The results of previous studies of sustained flight in triatomines suggest that the main source of flight energy is derived from oxidation of lipid and that the utilization of carbohydrates may take place only during the first minutes of flight, since glycogen content in flight muscles is rather low (Ward et al. 1982). $\alpha$-GPDH has a central role in lipid and carbohydrate metabolism, and in coupling the two processes (Bewley \& Miller 1979). One of its most important functions is to reoxidize NADH when flight muscle activity is based on glycolysis, but when tri-acyl glycerides are the flight fuel, this enzyme also acts to convert glycerol-3-phosphate derived from glycerol into dihidroxyacetone phosphate, a glycolytic intermediate. Our experimental design considered only flight initiation and not sustained flight, but the higher $\alpha$-GPDH activity in flying insects suggests that this enzyme may play an important role in triatomine flight and may be a useful marker to assess the proportion of potential fliers in natural populations of Triatominae.

\section{REFERENCES}

Bewley ER, Miller S 1979. Origin and differentiation of soluble alpha-glycerophosphate dehydrogenase isozyme in Drosophila melanogaster. In AR Liss, Current Topics in Biological and Medical Research, New York, p. 23-52.

Bradford MM 1976. A rapid and sensitive method for the quantification of microgram quantities of protein utilizing the principle of protein-dye binding. Analyt Biochem 72: 248-254.

Chambers GK, Felton AA, Ramshaw JAM, Rigby DL, Sullivan DT 1985. Structural analysis of glycerol3-phosphate dehydrogenase from several Drosophila species. Biochem Genet 23: 801-815.

Diotaiuti L, Loiola CF, Falcão PL, Dias JCP 1993. The ecology of Triatoma sordida in natural environments in two different regions of the State of Minas Gerais, Brazil. Rev Soc Bras Med Trop 35: 237-245.

Dujardin JP, Schofield CJ, Tibayrenc M 1998. Population structure of Andean Triatoma infestans: allozyme frequencies and their epidemiological relevance. Med Vet Entomol 12: 20-29.

Forattini OP, Ferreira AO, Rocha e Silva EO, Rabello EX 1977. Aspectos ecológicos da tripanossomose americana. VIII - Domiciliação de Panstrongylus megistus e sua presença extradomiciliar. Rev Saúde Públ 11: 73-86.

Lehane MJ, Schofield CJ 1981. Field experiments of dispersive flight by Triatoma infestans. Trans $R$ Soc Trop Med Hyg 75: 399-400.

Lehane MJ, McEwan P, Whitaker CJ, Schofield CJ 1992. The role of temperature and nutritional status in flight initiation by Triatoma infestans. Acta Trop 52: 2738.

Machado FM, Contel EP 1991. Glycerol-3-phosphate dehydrogenase isozyme variation in adult meliponids (Hymenoptera: Apidae). Biochem Genet 29: 255260.

Noireau F, Bosseno MF, Carrasco R, Telleria J, Vargas F, Camacho C, Yaksic N, Breniere SF 1995. Sylvatic triatomines (Hemiptera: Reduviidae) in Bolivia:

TABLE

$\alpha$-glycerophosphate dehydrogenase ( $\alpha$-GPDH) activity of fliers and non-fliers triatomines

\begin{tabular}{|c|c|c|c|c|}
\hline \multirow[b]{2}{*}{ Species } & \multirow[b]{2}{*}{ No. of fliers } & \multicolumn{3}{|c|}{ 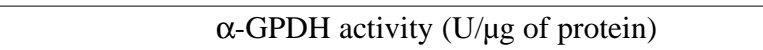 } \\
\hline & & Fliers & Non-fliers & $\mathrm{p}$ value \\
\hline Pans & $15 \%(15 / 100)$ & $0.134 \pm 0.052(15)$ & $0.068 \pm 0.036(15)$ & 0.0007 \\
\hline Triatoma. sordida & $52 \%(52 / 100)$ & $0.140 \pm 0.050$ & $0.093 \pm 0.040$ & 0.0200 \\
\hline
\end{tabular}

No. of insects in parentheses 
trends toward domesticity and possible infection with Trypanosoma cruzi (Kinetoplastida: Trypanosomatidae). J Med Entomol 32: 594-598.

O'Brien SJ, MacIntyre RJ 1972. The $\alpha$-glycerophosphate cycle in Drosophila melanogaster. I. Biochemical and developmental aspects. Biochem Genet 7: 141 .

Sacktor B 1970. Regulation of intermediary metabolism, with special reference to the control mechanisms in insect flight muscle. Adv Ins Phys 17: 167-347.

Sullivan DT, Donovan FA, Skuse G 1983. Developmen- tal regulation of glycerol-3-phosphate dehydrogenase synthesis in Drosophila. Biochem Genet 21: 49-62.

Valente SAS, Valente VC, Neves Pinto AY, Crescente JAB 1995. Epidemiologia dos reservatórios e vetores da infecção chagásica na Amazônia. Rev Soc Bras Med Trop 28 (Supl. III): 81-84.

Ward JP, Candy DJ, Smith SN 1982. Lipid storage and changes during flight by triatomine bugs (Rhodnius prolixus and Triatoma infestans). J Ins Physiol 28: 527-534. 